Relations industrielles

Industrial Relations

\title{
Gerald MARS : Cheats at Work. An Anthropology of Workplace Crime. London, Unwin Paperbacks, 1983, 242 pp., ISBN 0-04-301166-7
}

\section{Alexander J. Matejko}

\section{Volume 41, numéro 2, 1986}

URI : https://id.erudit.org/iderudit/050219ar

DOI : https://doi.org/10.7202/050219ar

Aller au sommaire du numéro

Éditeur(s)

Département des relations industrielles de l'Université Laval

ISSN

0034-379X (imprimé)

1703-8138 (numérique)

Découvrir la revue

Citer ce compte rendu

Matejko, A. J. (1986). Compte rendu de [Gerald MARS : Cheats at Work. An Anthropology of Workplace Crime. London, Unwin Paperbacks, 1983, 242 pp., ISBN 0-04-301166-7]. Relations industrielles / Industrial Relations, 41(2),

431-432. https://doi.org/10.7202/050219ar

Tous droits réservés (C) Département des relations industrielles de l'Université Laval, 1986
Ce document est protégé par la loi sur le droit d'auteur. L’utilisation des services d'Érudit (y compris la reproduction) est assujettie à sa politique d'utilisation que vous pouvez consulter en ligne.

https://apropos.erudit.org/fr/usagers/politique-dutilisation/ 
Cheats at Work. An Anthropology of Workplace Crime, by Gerald Mars, London, Unwin Paperbacks, 1983, pp. XII + 242, ISBN 0-04-301166-7

Occupational structures influence much the nature type and scale of fiddles that are practiced. The physically and socially restricted style of work operated by insulated and subordinate employees allows for a different kind of fiddles than in the case of individualized jobs (salesmen, etc.). The gap between 'working self' and 'fiddling self' is bridged by various personal justifications (one of them may be the alleged social injustice) as well as the reliance on the group support. "It is the groups worker's acceptance and absorption of groups assumptions that allows him to square his straight self with his sinful self. The two are insulated at one level but coalesce at another and thus ambiguity is resolved. Without group support, however, ambiguity remains unsolved» (p. 170). Most fiddles remain undetected because they are selfcontrolled or colluded in by management.

The vulnerability of various jobs to fiddling depends on their specific character conditioned by the constraints imposed on people occupying these jobs, as well as by the informal or semi-formal group affiliations. In the jobs characterized by high autonomy, insulation of their occupants from other people, high potential of reciprocity (the holder is able to give more than he/ she normally receives) and competition, the chances of fiddling are much different than in the jobs characterized by dependence, control by others, limited resources for exchange of favours, and no competition. As regards the group factor its potential depends on complementary tasks, frequency of interaction, scope of joint activities, mutually interconnecting network, a clear delineation between the group and the external world. Mars classifies fiddling people into 'donkeys' (grid + , group -) remaining in the isolated subordination, 'hawks' (grid - , group -) open to individual entrepreneurality, 'wolves' (grid + , group + ) acting in the tight work groups, and 'vultures' (grid -, group +) acting in the loose work groups. Strategy and tactics of cheating at work differs profoundly depending on the characteristics of a given job. The fiddle-prone factors are the passing trade (two sides to a transaction meet only once), ignorance of the client and his/her dependence on the external expertise, imbalance between supply and demand, alliance of two parties against a third, manipulation of effort and skill for the sake of bargaining, inefficient or impractical control, ambiguity of standards, the conversion and smuggling of goods, impersonality of big organizations.

Informal 'bargaining' with the system through fiddling on taxes and other formal duties or on expense of the clients and employers undermines the authority of the system. This is evident not only in the state socialist economies where the rigidity of official arrangement is constantly tested by the informal or semiformal effects of citizens to promote their private goals against the formal rules. In the democratic West the 'second economy' constitutes a substantial part of the total economy: one third in Italy, at least one tenth in the U.K. and in the U.S. The efforts to suppress this second economy are usually ineffective because any additional rigidity activates new fiddling better adapted to the changing circumstances. The harm is not only in the economic loss (primarily the lower state income from taxes) but in the demoralization of people and the disorganization of society.

According to Mars, «the danger of the changes facing us is that as a society we may continue to act only from the perspective of one occupational quadrant without appreciating the totality of concealed economic transactions and their place in a society subject to constant change. The alternative and hidden economies are too large to ignore, often too informal to detect, and too resilient to control. Inside and outside the workplace, fiddles often represent untapped potential» (p. 227). It is mainly the question how to harness and formalize for real awards informal initiatives of employees.» Corporations could recognize the dynamics of 'covert institutions' by translating them into an official modus operandi. The fiddler 'borrows' 
an organization's time and materials to further his own enterprise. Why should the organization not allow him - even encourage him - to borrow its resources for a price, renting him time on its production equipment line or feeding his ideas into the corporation's computers?» (p. 208).

The development of fiddling needs measures that would be appropriate, and one of them would be sub-contracting of specific tasks to small companies willing and able to gain profit from activities difficult to control and make really effective in the depersonalized big companies. This is a very important point brought by the author of the book.

Alexander J. MATEJKo

University of Alberta

Soft Sell: «Quality of Working Life» Programs and the Productivity Race, by Don Wells, Published by Canadian Centre for Policy Alternatives, 150 pages, Paper ISBN 0886270405

Soft Sell: "Quality of Working Life" Programs and the Productivity Race by Don Wells is an important contribution to the growing literature pertaining to workplace co-operative «experiments» from the perspective of the workers experience. The book analyzes two QWL programs in Ontario and probes beneath productivity gains to examine the impact of these programs upon workers and union security and solidarity, basic power relations and social relations in production, changes in work organization and job design, and actual worker involvement and participation in traditional management decision-making which impacts upon the day to day activities of ordinary workers.

The author finds that the actual practice and worker experience with both QWL programs falls short of the QWL «ideal» or goal as a process which emphasizes democratic principles in the workplace «and as a process based on joint control and shared responsibility between union and management at all levels». (p. 74) Rather, the author states that "QWL is designed to adjust workers to jobs, not jobs to workers. More broadly, it is designed to adjust workers to their own continuing subordination in the workplace». (p. 74) Far from enhancing the ability of workers or their unions to influence the decision that affect them, the whole tendency of QWL has been to undermine worker's power. (p. 75)

Mr. Wells describes just how both QWL initiatives, in fact, undermine the union and workers ability to influence management's right to dispose, layoff, introduce labour-saving devices, schedule production, and whatever to maintain what they deem to be appropriate levels of productivity and efficiency. The author further states that «management hopes workers will come to act like bosses» and the proponents of QWL assume that worker and management goals are compatible while hired and paid by management who «has a total monopoly of the purse». (p. 118) Mr. Wells warns workers and unions that «the QWL expert could not be neutral since he was an agent of management, hired by management, paid by management, and had no authority independent of management", (p. 118) and the effects of the program are, therefore, predictable: "Q.W.L. poses no challenge to management control» (p. 117) (emphasis mine) and that «there is nothing in the problem-solving techniques that teaches workers how to make their jobs into «good» ones with «enjoyment, accomplishment, and pride" or any other benefits QWL consultants talk about». (p. 104)

One cannot help but to conclude that it remains necessary for unions to pursue a genuine form of worker participation which would shift the focus of decision-making power to workers 